\title{
Small Cell Lung Cancer in Elderly Patients: A Review
}

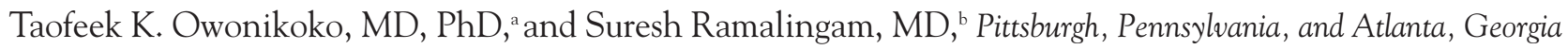

\section{Key Words}

Elderly, small cell lung cancer, limited-stage, extensive-stage, $\mathrm{PCl}$

\begin{abstract}
Small cell lung cancer (SCLC) accounts for approximately $13 \%$ of all lung cancer cases. Approximately $40 \%$ of those cases are diagnosed in patients older than 70 years, and this proportion continues to rise in contrast to the continued decline in incidence of SCLC among the general population. The optimal strategy to manage limitedstage SCLC involves a combined modality approach with platinumbased chemotherapy and external-beam thoracic radiation therapy. For extensive-stage disease, platinum-based combination chemotherapy is a mainstay of therapy. Elderly patients present unique challenges in terms of drug metabolism and organ reserve, which impact the outcome of therapeutic interventions. However, limited data are available to guide management decisions for SCLC in elderly patients, and therefore this article discusses recommendations for treatment. (JNCCN 2008;6:333-344)
\end{abstract}

The incidence of small cell lung cancer (SCLC) has decreased in the past 2 decades, ${ }^{1}$ and approximately $13 \%$ of all lung cancer patients have SCLC histology. ${ }^{1,2}$ Despite this, the proportion and, consequently, population of elderly patients with SCLC continues to rise. No generally accepted definition or chronologic age cutoff exists for elderly; use of the term varies across cultures and time periods. It is, however, a physical manifestation of the biologic process of aging: a progressive decline in cellular, organ, physical, and mental functioning. In the Western

\footnotetext{
From the aUniversity of Pittsburgh Cancer Institute, Pittsburgh, Pennsylvania, and bEmory Winship Cancer Institute, Atlanta, Georgia. Submitted October 1, 2007; accepted for publication November 9, 2007.

The authors have no financial interest, arrangement, or affiliation with the manufacturers of any products discussed in the article or their competitors.

Correspondence: Suresh Ramalingam, MD, Emory Winship Cancer Institute, 1365 Clifton Road, Suite \#C-5090, Atlanta, GA 30322. E-mail: Suresh.ramalingam@emory.edu
}

world, elderly generally refers to a period of accelerated decline in physical functioning. Some have used the age of 70 years as a cutoff, whereas others differentiate between elderly ( $<75$ years) and very elderly ( $>75$ years). The oldest old is the term coined for patients older than 85 years.

In the United States, approximately $42 \%$ of SCLC cases are diagnosed in patients older than 70 years, and $10 \%$ are diagnosed in patients older than 80 years. ${ }^{2}$ Elderly patients are significantly underrepresented in clinical trials, including those evaluating new treatment modalities for lung cancer. ${ }^{3-6}$ Although $63 \%$ of all cases occur in patients older than 65 years, an analysis of enrollment into 1 U.S. cooperative group trial between 1993 and 1996 showed that a minority of enrollees $(25 \%)$ were older than 65 years. ${ }^{3}$ This limits the applicability of data obtained from these clinical trials to the treatment of elderly patients, because physiologic changes related to aging and a higher prevalence of comorbid conditions influence the tolerance of systemic and local therapy and their efficacy. ${ }^{7}$ This article highlights the management and outcome of SCLC in elderly patients.

\section{Epidemiology}

SCLC is a tobacco-related cancer characterized by an explosive growth rate and high sensitivity to chemotherapy. The survival outcomes for patients with SCLC are generally poor. The incidence of SCLC in the United States continues to decline based on registry surveys, and it now constitutes about $13 \%$ of all lung cancer cases. However, the disease burden remains great because of a steady increase in the absolute number of cases as the elderly population grows. ${ }^{1,2}$ Of all lung cancer subtypes, SCLC shows the strongest association with tobacco exposure, with an odds ratio of 18 and 38 for intense tobacco use ( $>30$ cigarettes per day) and duration of smoking 
Owonikoko and Ramalingam

(> 40 years), respectively. ${ }^{8,9}$ Although the prevalence of smoking has decreased from $40 \%$ to $25 \%$ among adults in the United States because of public health measures, ${ }^{10}$ individuals still have a twofold increased risk for developing SCLC up to 25 years after smoking cessation. ${ }^{9}$

Emerging evidence shows that the incidence of SCLC in the elderly continues to increase. ${ }^{2,11}$ Analysis of the national Surveillance Epidemiology and End Results (SEER) database between 1988 and 2003 showed that $42 \%$ of all SCLC cases are diagnosed in patients older than 70 years, and approximately $10 \%$ occurred in patients older than 80 years. ${ }^{2}$ Temporal analysis of the data, however, showed a $10 \%$ increase in the proportion of SCLC diagnosed in patients 70 years or older when the decade from 1988 to 1997 was compared with the succeeding half decade, from 1998 to 2003. In contrast, the proportion of patients older than 80 years increased by almost $40 \%$ in the same period. ${ }^{2}$ The initial male predominance $(73 \%$ of all cases were men in 1973) has given way to gender parity, with a 1:1 distribution by $2002 .{ }^{1,11}$ This gender migration is largely attributable to the changing pattern of tobacco use in men and women. ${ }^{1,12}$ Given the generally better survival of women over men with lung cancer, ${ }^{2}$ this gender parity has the potential to result in increased prevalence and burden of the disease. The increased attention given to cancer in the elderly population is timely and should promote greater awareness of the scope of the problem, thereby promoting better care for this vulnerable patient population.

\section{Management of Limited-Stage SCLC Combined Chemotherapy and Radiation}

The standard therapy for limited-stage SCLC in the general patient population consists of a combination of platinum-based chemotherapy and external beam thoracic radiation. ${ }^{13-15}$ The median age of patients enrolled into the initial trials of combination chemotherapy in SCLC was 65 years or older, reflecting that the regimens were tested in a fair proportion of elderly patients. ${ }^{13,14}$ In the pivotal phase III randomized trial that compared cisplatin/etoposide with cyclophosphamide, epirubicin, and vincristine (CEV) for limited-stage disease, the median age of patients was 65 years. ${ }^{14}$ The cisplatin/etoposide regimen showed a superior 2 -year survival rate $(25 \%$ vs. $10 \%)$. This study supports the observation that elderly patients tolerate the cisplatin/etoposide regimen well and experience benefit.

The development and introduction of carboplatin into clinical use provided an alternative platinum agent with marked reduction in nephrotoxicity and neurotoxicity and a lower incidence of nausea and vomiting. ${ }^{16,17}$ Carboplatin was tested as an alternative agent to cisplatin in multiple trials enrolling elderly patients. ${ }^{18-22}$ Skarlos et al. ${ }^{18}$ compared the efficacy of carboplatin/etoposide combination with cisplatin/etoposide in an unselected, previously untreated population of patients with SCLC (both limited-and extensive-stage). The patient age ranged from 34 to 78 years. ${ }^{18}$ This study showed a significant reduction in the incidence of hematologic and nonhematologic toxicities with comparable response rates ( $57 \%$ vs. $58 \%$ ) and median survival outcomes (12.5 vs. 11.8 months) for the carboplatin-based regimen. ${ }^{18}$

Because area-under-the-curve (AUC)-based dosing was adopted over body surface area-based dosing, several studies have evaluated carboplatin-based regimens in elderly patient populations using the AUC dosing method. ${ }^{19,20}$ Okamoto et al. ${ }^{19}$ conducted a phase II trial using carboplatin ( $\mathrm{AUC}=5$ ) with etoposide in an elderly patient population (median age, 73 years). They reported grade 4 leukopenia and thrombocytopenia of $3 \%$ and $11 \%$, respectively, with an objective response rate of $75 \% .{ }^{19}$ A phase I study was recently conducted to evaluate a lower dose of carboplatin in patients older than 75 years. Carboplatin was dosed to achieve an AUC of 4 in combination with etoposide. The response rate of $69 \%$ suggested that the efficacy was not compromised by the use of a lower dose of carboplatin. ${ }^{23}$ However, grade 4 hematologic toxicity was still noted in $62 \%$ of the patients, although the rate of renal toxicity was low at $4 \%{ }^{23}$ (Table 1 ).

Several other studies have evaluated lower doses, reduced number of cycles, or alternative treatment schedules to improve the safety profile of combination regimens in elderly patients. Studies conducted with reduced cycles of chemotherapy and abbreviated radiation therapy have shown acceptable response rates with survival that is comparable with standard courses of therapy. ${ }^{21,31}$ Murray et al. ${ }^{21}$ investigated the use of only 2 cycles of chemotherapy (cyclophosphamide, doxorubicin, vincristine [CAV] followed by cisplatin and etoposide) with abbreviated concurrent thoracic irradiation to $30 \mathrm{~Gy}$ in 55 patients with limited-stage SCLC who were elderly or had poor per- 
Small Cell Lung Cancer in the Elderly

\begin{tabular}{|c|c|c|c|c|c|c|c|}
\hline Trial & $\begin{array}{l}\text { Median } \\
\text { Age (y) }\end{array}$ & $\begin{array}{l}\text { Extent of } \\
\text { Disease }\end{array}$ & $\begin{array}{l}\text { Number of } \\
\text { Patients }\end{array}$ & Therapy & $\begin{array}{l}\text { Response } \\
\text { Rate (\%) }\end{array}$ & $\begin{array}{l}\text { Median } \\
\text { Survival }\end{array}$ & Remarks \\
\hline Goss et al. ${ }^{24}$ & 63 & $\begin{array}{l}\text { LD } \\
\text { ED }\end{array}$ & $\begin{array}{l}29 \\
33\end{array}$ & $\mathrm{CT}$ & $\begin{array}{l}76 \text { (48\% CR) } \\
76 \text { ( } 21 \% \text { CR) }\end{array}$ & 59 wk & $\begin{array}{l}\text { TRT and } \mathrm{PCl} \text { used in } \\
\text { patients with LD }\end{array}$ \\
\hline Michel et al. ${ }^{25}$ & 72 & $\begin{array}{l}\text { LD } \\
\text { ED }\end{array}$ & $\begin{array}{l}8 \\
16\end{array}$ & $\mathrm{CT}$ & 67 (20\% CR) & 33 wk & \\
\hline Evans et al. ${ }^{26}$ & 67 & $\begin{array}{l}\text { LD } \\
\text { ED }\end{array}$ & $\begin{array}{l}11 \\
36\end{array}$ & CE & $\begin{array}{l}88 \text { (50\% CR) } \\
67 \text { (23\% CR) }\end{array}$ & $\begin{array}{l}12.2 \mathrm{mo} \\
10.8 \mathrm{mo}\end{array}$ & \\
\hline Matsui et al. ${ }^{27}$ & N/A & $\begin{array}{l}\text { LD } \\
\text { ED }\end{array}$ & $\begin{array}{l}16 \\
22\end{array}$ & CE & $\begin{array}{l}93 \\
71\end{array}$ & $\begin{array}{l}15.1 \mathrm{mo} \\
8.6 \mathrm{mo}\end{array}$ & \\
\hline Okamoto et al. ${ }^{19}$ & 73 & $\begin{array}{l}\text { LD } \\
\text { ED }\end{array}$ & $\begin{array}{l}16 \\
20\end{array}$ & CE & $\begin{array}{l}63 \\
85\end{array}$ & $\begin{array}{l}11.6 \mathrm{mo} \\
10.1 \mathrm{mo}\end{array}$ & \\
\hline Quoix et al. ${ }^{28}$ & $>70$ & LD/ED & 38 & $\mathrm{CE}$ & 76 & $7.9 \mathrm{mo}$ & \\
\hline Matsui et al. ${ }^{20}$ & $>70$ & $\begin{array}{l}\text { LD } \\
\text { ED }\end{array}$ & $\begin{array}{l}11 \\
6\end{array}$ & CE & 94 & $12 \mathrm{mo}$ & \\
\hline Larive et al. ${ }^{29}$ & 74 & $\begin{array}{l}\text { LD } \\
\text { ED }\end{array}$ & $\begin{array}{l}6 \\
28\end{array}$ & CE & 59 (9\% CR) & $9 \mathrm{mo}$ & \\
\hline Okamoto et al. ${ }^{30}$ & $>70$ & $\begin{array}{l}\text { LD } \\
\text { ED }\end{array}$ & $\begin{array}{l}8 \\
10\end{array}$ & $\mathrm{Cl}$ & 89 (11\% CR) & $13.3 \mathrm{mo}$ & $\begin{array}{l}50 \% \text { of patients } \\
\text { underwent } \\
\text { prior treatment }\end{array}$ \\
\hline
\end{tabular}

Abbreviations: $\mathrm{CE}$, carboplatin and etoposide; $\mathrm{Cl}$, carboplatin and irinotecan; $\mathrm{CR}$, complete response; $\mathrm{CT}$, carboplatin and teniposide; ED, extensive-stage disease; LD, limited-stage disease; N/A, not available; PCI, prophylactic cranial irradiation; TRT, thoracic radiation therapy.

formance status (median age, 73 years). The objective response rate was $88 \%$, with a complete response rate of $51 \%$, and $18 \%$ of the patients were alive at 5 years. Although patients tolerated the regimen well overall, 3 treatment-related deaths occurred.

However, subsequent larger clinical trials that compared full- and reduced-intensity chemotherapy did not substantiate the promising efficacy of this approach $^{32-34}$ (Table 2). Based on these observations, using empiric dose reduction to treat elderly SCLC patients does not necessarily lead to an improved therapeutic index.

The addition of thoracic radiation to platinumbased chemotherapy is associated with survival advantage in limited-stage SCLC, and confers a 30\% increase in disease control in the chest and up to 14\% improvement in mortality. ${ }^{37-39}$ However, subset analysis showed that this benefit was mainly confined to patients younger than 55 years, with a trend toward adverse outcome in patients aged 70 years and older. ${ }^{37}$ The absolute benefit from thoracic radiation is approximately a $5.4 \%$ increase in the 3 -year survival rate. ${ }^{40,41}$

Further efforts at improving the impact of thoracic radiation in limited-stage SCLC led Turrisi et al. ${ }^{42}$ to evaluate a hyperfractionated dose in an Intergroup study (INT 0096), administering 45 Gy over 3 weeks in 1.5-Gy dosages twice daily. This large randomized study established the superiority of the hyperfractionated schedule over once-daily fractionation (5-year survival rate, $26 \%$ vs. $15 \%$ ) with a sizable representation of the elderly ( $31 \%$ of patients randomized to the twice-daily radiation therapy were $\geq 65$ years). ${ }^{42}$

This treatment regimen has, however, been difficult to integrate into regular clinical practice, and an analysis of the pattern of care for patients with lung cancer in major United States institutions showed that only $6 \%$ of those with SCLC received twice-daily radiation therapy. ${ }^{43}$ Moreover, this regimen may be especially difficult to use in the elderly given the increased incidence of grade 3 esophagitis ( $27 \%$ vs. $11 \% ; P=.001$ ), grade 2 or 3 weight loss ( $35 \%$ vs. $26 \% ; P=.05),{ }^{33}$ and the logistic limitations with twice-daily radiation. The potential for treatment delays with this regimen is also a concern, because the interval between initiation and completion of radiotherapy, especially with platinumbased chemoradiotherapy, is an important predictor of outcome in this group of patients, and treatment delays or interruptions can lead to inferior outcomes. ${ }^{44}$ 
Owonikoko and Ramalingam

\begin{tabular}{|c|c|c|c|c|c|c|}
\hline Trial & $\begin{array}{l}\text { Age } \\
\text { Cutoff (y) }\end{array}$ & $\begin{array}{l}\text { No. of } \\
\text { Patients }\end{array}$ & Intervention & $\begin{array}{l}\text { Response } \\
\text { Rate }\end{array}$ & Survival & Remarks \\
\hline Findlay et al. ${ }^{35}$ & $\geq 70$ & $\begin{array}{l}26 \mathrm{LD}+ \\
46 \mathrm{ED}\end{array}$ & $\begin{array}{l}\text { Full-dose CAV } \\
\text { Reduced-dose } \\
\text { CAV/single } \\
\text { agent/XRT alone }\end{array}$ & $\begin{array}{l}84 \% \\
52 \%\end{array}$ & $\begin{array}{l}36 w k \\
16 w k\end{array}$ & $\begin{array}{l}\text { Single-institution } \\
\text { retrospective chart } \\
\text { review; more toxicity } \\
\text { with intensive regimen } \\
\text { with } 3 \text { therapy-related } \\
\text { deaths }\end{array}$ \\
\hline \multirow[t]{3}{*}{ Shepherd et al. ${ }^{36}$} & \multirow[t]{3}{*}{$\geq 70$} & \multirow[t]{3}{*}{126 LD + ED } & No therapy & \multirow[t]{3}{*}{ N/A } & & \multirow{3}{*}{$\begin{array}{l}\text { Single-institution } \\
\text { retrospective chart review }\end{array}$} \\
\hline & & & $\begin{array}{l}\text { Reduced-intensity } \\
\text { chemotherapy } \\
\text { (<3 cycles) }\end{array}$ & & $3.9 \mathrm{mo}$ & \\
\hline & & & $\begin{array}{l}\text { Full-intensity } \\
\text { chemotherapy } \\
\text { (4-6 cycles) }\end{array}$ & & $10.7 \mathrm{mo}$ & \\
\hline Souhami et al. ${ }^{33}$ & $>75$ & $\begin{array}{l}11 \mathrm{LD}+ \\
138 \mathrm{ED}+ \\
6 \mathrm{UK}\end{array}$ & $\begin{array}{l}\text { Oral etoposide } \\
\times 6 \text { cycles } \\
\text { vs. } \\
\text { Intravenous } \\
\text { CAV x } 6 \text { cycles }\end{array}$ & $32.9 \%$ & $5.9 \mathrm{mo}$ & $\begin{array}{l}\text { Phase II comparative trial; } \\
\text { patients aged < } 75 \text { y with } \\
\text { extensive disease } \\
\text { allowed on trial; early } \\
\text { accrual stoppage because } \\
\text { of inferior outcome in the } \\
\text { reduced intensity arm on } \\
\text { interim analysis }\end{array}$ \\
\hline Jeremic et al. ${ }^{31}$ & $\geq 70$ & 72 & $\begin{array}{l}\text { Cis/E x } 2 \\
+ \\
\text { XRT 45Gy }\end{array}$ & $75 \%$ & $15 \mathrm{mo}$ & $\begin{array}{l}\text { Phase II study } \\
\text { Accelerated and } \\
\text { hyperfractionated } \\
\text { XRT dose }\end{array}$ \\
\hline Murray et al. ${ }^{21}$ & $73 *$ & 55 & $\begin{array}{l}\text { CAV x } 1 \\
+ \\
\text { Cis/E x } 1 \\
+ \\
\text { XRT 30Gy }\end{array}$ & $89 \%$ & $12.3 \mathrm{mo}$ & $\begin{array}{l}\text { Phase II limited-stage } \\
\text { disease only; } 18 \text { patients } \\
\text { aged }<70 \text { y }\end{array}$ \\
\hline Ardizzoni et al. ${ }^{34}$ & $>70$ & $\begin{array}{l}52 \mathrm{LD}+ \\
43 \mathrm{ED}\end{array}$ & $\begin{array}{l}\mathrm{Cis} / \mathrm{E} \\
25 \mathrm{mg} / 60 \mathrm{mg} \\
\text { vs. } \\
\text { Cis/E } \\
40 \mathrm{mg} / 100 \mathrm{mg}\end{array}$ & $69 \%$ & $41 \mathrm{wk}$ & $\begin{array}{l}\text { Phase III study; growth } \\
\text { factor support given with } \\
\text { the full-dose chemotherapy }\end{array}$ \\
\hline
\end{tabular}

*Median age of enrolled patients.

Abbreviations: CAV, cyclophosphamide, doxorubicin, vincristine; Cis/E, cisplatin and etoposide; ED, extensive-stage disease; LD, limited-stage disease; N/A, not available; UK, unknown stage; XRT, external-beam radiation therapy.

Whether the benefit from hyperfractionated schedules of thoracic radiation applies to the elderly remains controversial based on weak evidence to the contrary from meta-analysis of randomized trials. ${ }^{37}$ In the absence of a prospective elderly-specific trial to answer this question, a retrospective analysis was conducted to compare the outcomes between younger and elderly patients enrolled in INT 0096, which evaluated the benefit of once-daily versus split-dose radiotherapy in combination with cisplatin-based chemotherapy. ${ }^{45}$ Of the original 417 patients, 381 were eligible for the secondary analysis, of which 50 (13\%) were older than 70 years. Comparable outcomes were seen in terms of response rate $(80 \%$ in 
Small Cell Lung Cancer in the Elderly

the elderly vs. $88 \%$ for younger patients; $P=.11$ ), 5 -year event-free survival ( $16 \%$ for the elderly vs. $19 \%$ for younger patients; $P=.18$ ), duration of response, and time to local failure between elderly and younger patients. Despite the reduced rate of dose delivery in the elderly ( $78 \%$ received the target of 4 cycles of chemotherapy compared with $90 \%$ of younger patients), they experienced a significant increase in severe hematologic toxicities ( $84 \%$ vs. $61 \%$; $P<.01)$ and fatal toxicities $(10 \%$ vs. $1 \%, P=.01)$, which probably contributed to the inferior 5 -year overall survival ( $16 \%$ vs. $22 \% ; P=.05)$ recorded for the elderly group in this secondary analysis. ${ }^{45}$

Similar findings were reported in a secondary analysis of a different prospective trial by the North Central Cancer Treatment Group (NCCTG), also designed originally to answer the question of single versus twice-daily radiation in combination with chemotherapy in patients with limited-stage SCLC. ${ }^{46}$ Of 263 enrolled patients, 54 (21\%) were aged 70 years or older. A comparison of this elderly cohort with their younger counterparts showed no significant difference in survival outcome or disease control rate (2-year survival rates of $48 \%$ vs. $33 \%$, respectively, and 5 -year survival rates of $22 \%$ vs. $17 \%$, respectively, for younger vs. elderly patients; $P=.14$ ). However, a significantly higher incidence of pneumonitis in the elderly $(0 \%$ vs. $6 \% ; P=.008)$ and a tenfold greater treatment-related mortality $(0.5 \%$ vs. $5.6 \% ; P=.03)$ were seen. Other early-phase clinical trials for limitedstage SCLC have explored alternative strategies with once-daily therapy to a higher total dose of 70 Gy or twice-daily therapy to a higher dose with planned treatment breaks, although these have not been tested specifically in elderly patients. . $^{41,47,48}$

Based on these data, fit elderly patients with limited-stage SCLC should be offered cisplatin- over carboplatin-based regimens. However, the higher degree of cisplatin-related toxicity warrants particular caution for elderly patients, especially those older than 75 years. These patients tend to have a higher burden of comorbid illnesses and suboptimal performance status, in which case a carboplatin-based regimen may represent a reasonable alternative. Thoracic radiation concurrent with chemotherapy remains standard care for treating limited-stage SCLC and should be judiciously used. In elderly patients, twice-daily radiation should only be used for those with excellent performance status and no major comorbid illness, because it is associated with increased treatment-related fatalities in this population.

\section{Management of Extensive-Stage SCLC}

The NCCN Clinical Practice Guidelines in Oncology: Small Cell Lung Cancer (in this issue; to view the most recent version, please visit the NCCN Web site at www.nccn.org) recommend 4 to 6 cycles of platinumbased combination chemotherapy as standard treatment for patients with extensive-stage SCLC. ${ }^{49}$ Cisplatin (75-80 mg) or carboplatin (AUC 5-6) in combination with etoposide is the commonly used frontline regimen. Despite the suggestion of a slight survival advantage with cisplatin-containing regimens by 2 meta-analyses of SCLC trials, ${ }^{50,51}$ the favorable toxicity profile of carboplatin/etoposide over cisplatin/etoposide supports its preferential use in elderly patients, where it has been extensively studied. $23,28,29$

In a study of 38 previously untreated elderly patients (age range, $70-88$ years) with predominantly extensive-stage disease, the combination of carboplatin (AUC 5) and etoposide $\left(100 \mathrm{mg} / \mathrm{m}^{2}\right.$ intravenously days $1-3)$ yielded an objective response rate of $60 \%$ and a 1 -year survival rate of $26 \% .^{28}$ The main toxicities were hematologic (grade 4 neutropenia of $31 \%$ and grade 4 thrombocytopenia of $12 \%$ ), with no treatment-related renal toxicity. Although $29 \%$ of enrolled patients died during therapy, only 2 of the 11 deaths were clearly treatment-related. Moreover, other trials using the same combination of agents at similar doses in elderly patients have shown a favorable safety profile..$^{29,52,53}$

The first phase III trial of cisplatin/etoposide versus carboplatin/etoposide in patients who were elderly or had poor performance status with extensive-stage SCLC was published recently. ${ }^{53}$ The trial enrolled 220 patients with median age of 74 years, with $92 \%$ older than 70 years. The response rate was $73 \%$ in both arms, with a trend toward better median overall survival for the carboplatin arm (10.6 vs. 9.9 months; $P=.054)$. A very high rate of grade 3 or 4 neutropenia was recorded in both arms (95\% and 90\%), but the rate of grade 3 or 4 infection was relatively low ( $7 \%$ and $6 \%$; $P=.78)$, reflecting the use of growth factor support in more than $50 \%$ of patients in each cohort. The only significant difference in the toxicity profiles of both regimens is the higher rate of thrombocytopenia in the carboplatin arm $(56 \%$ vs. $16 \% ; P<.01)$. Although mild renal impairment (grade 1 or 2 ) was 3 times as common 
Owonikoko and Ramalingam

with cisplatin as with carboplatin, the clinically relevant grade 3 or 4 renal impairment was rare in both arms. Although the study had limitations, such as the use of potentially suboptimal cisplatin dosage schedule, it nonetheless provided valuable information about the efficacy of the carboplatin/etoposide combination as an alternative to split-dose cisplatin/etoposide in patients who were elderly or had poor performance status..$^{53}$

The other promising regimen tested in extensivestage SCLC is the cisplatin and irinotecan combination. A phase III study conducted in Japan by Noda et al. ${ }^{54}$ showed superior survival with cisplatin/irinotecan over cisplatin/etoposide. This trial randomized 154 patients to receive cisplatin $80 \mathrm{mg} / \mathrm{m}^{2}$ plus etoposide $100 \mathrm{mg} / \mathrm{m}^{2}$ (days $1-3$ ) repeated every 4 weeks or cisplatin $\left(60 \mathrm{mg} / \mathrm{m}^{2}\right)$ and irinotecan $\left(60 \mathrm{mg} / \mathrm{m}^{2}\right.$ on days 1,8 , and 15) repeated every 4 weeks. The study was closed early after an interim analysis showed that patients in the irinotecan arm had superior survival (12.8 vs. 9.4 months, $P=.002)$. A significantly higher frequency of grade 3 or 4 diarrhea occurred (16\% vs. $0 \%)$, which led to the day-15 irinotecan dose to be skipped in $50 \%$ of patients. However, this study excluded patients older than 70 years.

In a confirmatory study conducted by Hanna et al., ${ }^{55} 331$ patients with extensive-stage SCLC were randomized (2:1) to treatment with cisplatin/irinotecan or cisplatin/etoposide. Approximately $45 \%$ of patients were older than 65 years. In an attempt to improve the safety profile of the cisplatin-irinotecan regimen, the dose schedule for irinotecan $\left(60 \mathrm{mg} / \mathrm{m}^{2}\right)$ was modified to be given only on days 1 and 8 . The survival advantage reported in the Japanese trial (Noda et $a .^{54}$ ) was not observed in this study (9.3 vs. 10.2 months; $P=.74$ ) and no significant improvement was recorded in the nonhematologic toxicity profile of the irinotecan regimen (grade 3 or 4 diarrhea, 21.3\% vs. $0 \% ; P<.01)$ despite skipping the day- 15 dose. The reason for the negative result in this study remains speculative, including changes in the dose schedule and pharmacogenomic differences between the patient populations. An ongoing trial by SWOG using the exact regimen used in the Japanese trial has completed accrual and will hopefully provide insight into the potential benefit of the irinotecan-based regimen. ${ }^{56}$

Another recently reported study compared the use of irinotecan/carboplatin with etoposide/carboplatin. The study included 209 patients, with approximately $30 \%$ of patients older than 70 years. The 2 treatment arms were irinotecan $\left(175 \mathrm{mg} / \mathrm{m}^{2}\right.$ intravenously on day 1$)$ with carboplatin (AUC 4) or etoposide $\left(120 \mathrm{mg} / \mathrm{m}^{2}\right.$ orally) plus carboplatin (AUC 4) every 3 weeks. Both arms had a high-dose delivery rate of $93 \%$, with increased rate of grade 3 or 4 thrombocytopenia in the etoposide arm ( $26 \%$ vs. $11 \% ; P=.05)$ and increased grade 3 or 4 diarrhea in the irinotecan arm ( $1 \%$ vs. $11 \%$; $P=.003)$. The irinotecan/carboplatin combination was associated with a higher complete response rate (18 vs. 7 patients) and improved median and 1-year survival (8.5 vs. 7.1 months and $34 \%$ vs. $24 \%$, respectively; $P=.002) .{ }^{57}$ In summary, the role of irinotecan for the treatment of SCLC remains to be proven for the North American patient population. Considering the toxicities, particularly diarrhea associated with the combination of irinotecan and a platinum compound, data from elderly-specific trials are warranted before it becomes routine practice.

In conclusion, available evidence supports the treatment of elderly patients with platinum-based chemotherapy for the treatment of extensive-stage SCLC. Given the better toxicity profile and comparable efficacy from the limited data from elderly-specific trials, using carboplatin (in combination with etoposide) is a reasonable alternative to cisplatin-based therapy. The efficacy of irinotecan in SCLC for the general Western population remains to be shown and therefore cannot be recommended for routine use in the elderly patients.

\section{Prophylactic Cranial Irradiation}

Patients with limited-stage disease who experience complete remission of their disease after combined modality therapy with chemotherapy and thoracic radiation are recommended to undergo prophylactic cranial irradiation $(\mathrm{PCI}){ }^{49}$ Several small prospective studies showed reduced incidence of brain metastasis after PCI, but lacked enough power to show a survival advantage. ${ }^{58-60}$ However, results of meta-analyses using pooled individual patient data showed that PCI confers a survival advantage, especially with patients experiencing complete remission ${ }^{61-63}$ A $54 \%$ relative risk reduction occurred in incidence of brain metastasis, which translated into a 5.4- and 8.8-month absolute improvement in 3-year overall survival and disease-free survival respectively. ${ }^{62}$ This benefit was shown in all age groups, including patients older than 65 years. ${ }^{62}$

Because of concerns about the potential for neurocognitive impairment, such as memory loss, 
Small Cell Lung Cancer in the Elderly

intellectual degradation, and motor abnormalities, retrospective studies have evaluated the safety of PCI in elderly patients. ${ }^{64}$ These concerns have caused practitioners to be reluctant to offer PCI to elderly patients with SCLC. In a retrospective analysis of registry data in Vancouver, Canada, Ludbrook et al.$^{65}$ showed that PCI was offered at a significantly lower rate to elderly patients older than 75 years. The low rate of PCI in the elderly is probably unrelated to performance status or comorbid conditions, because the same analysis showed that the rate for thoracic radiation, both total-dose and fractionation, were not significantly different among younger and older patient groups. Although substantive evidence from prospective short- and medium-term follow-up of patients is lacking about this potential complication, ${ }^{60,64,66,67}$ some studies reported significant neurotoxicity on longterm follow-up of patients with SCLC ${ }^{68-70}$ (Table 3). This problem has been difficult to study because no standard approach to evaluation exists across clinical trials, and the available tools are not well validated. Moreover, the lung cancer patient population is elderly with a higher likelihood of preexisting or newly diagnosed neurocognitive impairment, irrespective of treatment intervention, thereby further confounding the potential relationship between any observed cognitive abnormality and the disease state or treatment modality.

In a prospective study evaluating neuropsychiatric function before PCI in 46 patients with newly diagnosed limited-stage SCLC, $80 \%$ had impaired memory, $38 \%$ had frontal lobe executive function impairment, and a third had motor deficits. ${ }^{67} \mathrm{~A}$ larger longitudinal study involving 432 patients with SCLC showed that a neurologic diagnosis was established in approximately $65 \%$ on long-term follow-up, but approximately half of the abnormalities were present at diagnosis before any intervention. ${ }^{75}$ Most patients with SCLC rarely survive long enough to manifest this potential complication of PCI; whereas brain-only relapse is highly fatal because it is poorly responsive to chemotherapy or radiation. ${ }^{76,77}$ Therefore, PCI should be considered and judiciously used in selected elderly patients with limited-stage disease who achieve complete remission, and do not suffer from preexisting neurocognitive impairment or any other comorbidities that may otherwise impair long-term survival.

At diagnosis, approximately $18 \%$ to $24 \%$ of patients with SCLC have brain metastasis, ${ }^{75,78}$ and up to $70 \%$ of patients with extensive-stage disease will develop brain metastasis within 2 years of diagnosis, com- pared with $47 \%$ of patients with limited-stage disease. ${ }^{79}$ Despite this, patients with extensive-stage disease were not considered for PCI because of the generally poor outcome, with a 5-year overall survival rate of less than $5 \%$ in patients older than 70 years. ${ }^{2,80}$ They were also likely to be excluded from trials evaluating the role of PCI because of findings from earlier meta-analyses showing that the benefit of PCI is limited to patients with good-prognosis disease. ${ }^{61,62}$

However, evidence is emerging of the usefulness of $\mathrm{PCI}$ in patients with extensive-stage SCLC who experienced demonstrable but not necessarily complete response to chemotherapy. Slotman et al ${ }^{81}$ randomized 286 patients with extensive-stage SCLC to undergo $\mathrm{PCI}$ or observation after experiencing demonstrable response to 4 to 5 cycles of standard chemotherapy, and noted a reduced incidence of brain metastasis in the PCI arm (16.8\% vs. $41.3 \% ; P<.001)$ and a doubling of the 1 -year survival rate $(27.1 \%$ vs. $13.3 \% ; P<.003)$. The study excluded patients older than 75 years, and the median participant age was 62 years.

An important limitation of the promising result obtained in this study is the poor standardization of imaging modality and schedule that was adopted across participating centers. The requirement of symptomatic brain metastasis to trigger radiologic evaluation rather than active radiologic surveillance means that some patients with asymptomatic disease inadvertently underwent active treatment in the PCI arm, and their number may be large enough to be responsible for the observed differences. It is well-established that systemic response does not predict brain response and patients with untreated asymptomatic brain metastasis have worse survival than patients with symptomatic disease treated with whole brain radiation. ${ }^{78}$

Despite these limitations, the results of this study support the use of PCI for patients with extensive-stage SCLC after they experience objective response to chemotherapy. However, the applicability of these findings to elderly patients is unclear. Although the study allowed the inclusion of patients up to 75 years of age, most were younger, with median age of 62 years. Therefore, the risk-benefit ratio of PCI for extensive-stage disease in the very elderly has not been established. Nonetheless, the impressive positive results of the EORTC study along with the established benefit of PCI in limited-stage disease strengthen the need for a careful evaluation of PCI in the elderly patient population. 
Owonikoko and Ramalingam

\begin{tabular}{|c|c|c|c|c|c|c|}
\hline Study & $\begin{array}{l}\text { Median } \\
\text { Follow- } \\
\text { Up (y) }\end{array}$ & $\begin{array}{l}\text { Radiation } \\
\text { Dose and } \\
\text { Fraction }\end{array}$ & No. of Patients & $\begin{array}{l}\text { Isolated Brain } \\
\text { Relapse }\end{array}$ & $\begin{array}{l}\text { Rate of } \\
\text { Neurotoxicity } \\
\text { in Long-Term } \\
\text { Survivors }\end{array}$ & Remarks \\
\hline Johnson et al. ${ }^{68}$ & 6.7 & $\begin{array}{l}20-50 \mathrm{~Gy} \\
5-25 \mathrm{~Gy}\end{array}$ & $\begin{array}{l}\text { PCl: } 17 \\
\text { No PCl: } 3\end{array}$ & $\mathrm{~N} / \mathrm{A}$ & $\begin{array}{l}62 \% \text { * } \\
89 \% *\end{array}$ & $\begin{array}{l}\text { Neurotoxicity measured by score on } \\
\text { MMSE }\end{array}$ \\
\hline Lee et al. ${ }^{69}$ & $\geq 3$ & Variable & PCl: 24 & $N / A$ & $3 \%$ & \\
\hline & & & No PCl: 14 & & $0 \%$ & \\
\hline Ohonoshi et al. ${ }^{71}$ & 8.5 & $\mathrm{~N} / \mathrm{A}$ & $\begin{array}{l}\mathrm{PCl}: 23 \\
\text { No PCl: } 23\end{array}$ & $\begin{array}{l}22 \% \\
52 \%\end{array}$ & $14 \%$ & \\
\hline Shaw et al. ${ }^{72}$ & 4 & $\begin{array}{l}30-38 \mathrm{~Gy} \\
2-3.6 \mathrm{~Gy}\end{array}$ & $\begin{array}{l}\text { LD: } 457 \mathrm{PCl} \\
\text { No PCI } \\
\text { ED: } 200 \mathrm{PCl} \\
\text { No PCI }\end{array}$ & $\begin{array}{l}9 \% \\
37 \% \\
8 \% \\
31 \%\end{array}$ & $10 \%$ at $5 y$ & $\begin{array}{l}\text { The neurotoxicity rate is for all } \\
\text { patients }(L D+E D) \text { receiving } P C I\end{array}$ \\
\hline Cull et al. ${ }^{73}$ & 2 & Variable & 52 & $\mathrm{~N} / \mathrm{A}$ & $54 \%$ & $\begin{array}{l}\text { Patients surviving beyond }>2 \mathrm{y} \\
\text { were recalled for neuropsychometric } \\
\text { testing }\end{array}$ \\
\hline Arriagada et al. ${ }^{59}$ & 5 & 24-36 Gy & $\begin{array}{l}\text { PCI: } 149 \\
\text { No PCl: } 151\end{array}$ & $\begin{array}{l}19 \% \\
45 \%\end{array}$ & $\begin{array}{l}27 \% \text { at } 2 y \\
25 \% \text { at } 2 y\end{array}$ & $\begin{array}{l}\text { The recorded rate of neurotoxicity } \\
\text { is the mean frequency at } 7 \text { different } \\
\text { domains tested }\end{array}$ \\
\hline Gregor et al. ${ }^{60}$ & 2 & $\begin{array}{l}24-36 \text { Gy } \\
2 \text { Gy }\end{array}$ & $\begin{array}{l}\text { PCl: } 194 \\
\text { No PCl: } 120\end{array}$ & $\begin{array}{l}30 \% \\
54 \%\end{array}$ & $\begin{array}{l}29 \% \text { at } 1 y \\
28 \% \text { at } 1 y\end{array}$ & $\begin{array}{l}\text { Recorded rate is mean frequency } \\
\text { from } 4 \text { different domains tested }\end{array}$ \\
\hline Wolfson et al. ${ }^{74}$ & 2 & $\begin{array}{l}30-36 \mathrm{~Gy} \\
1.5 \mathrm{~Gy} \text { bid }\end{array}$ & $\begin{array}{l}\text { PCl: } 15 \\
\text { No PCl: } 12\end{array}$ & $\begin{array}{l}13 \% \\
25 \%\end{array}$ & $\begin{array}{l}6 \% \\
0 \%\end{array}$ & $\begin{array}{l}\text { Study used twice daily brain } \\
\text { irradiation; the only patient with } \\
\text { neurologic symptom was found } \\
\text { to have brain metastasis }\end{array}$ \\
\hline
\end{tabular}

*Scores on MMSE where lower value reflects poorer performance and indicates increased neurotoxicity.

Abbreviations: ED, extensive-stage disease; LD, limited-stage disease; MMSE, Mini Mental State Examination; N/A, not available; $\mathrm{PCl}$, prophylactic cranial irradiation.

\section{Salvage Therapy for Resistant and Relapsed Disease}

The outcome for patients with relapsed or refractory SCLC remains poor, despite extensive evaluation of several novel agents. A wide array of chemotherapeutic agents, such as ifosfamide, taxanes, gemcitabine, irinotecan, vinorelbine, and topotecan, have all been found to be associated with meager response rates and survival in this setting. ${ }^{49}$

Intravenous topotecan is the most frequently used regimen in the second-line setting and has received FDA approval for this indication. It was evaluated in a phase III trial against the CAV regimen (cyclophosphamide, doxorubicin, and vincristine) in 211 patients who experienced relapse. ${ }^{82}$ No significant difference was seen in the response rate $(24.3 \%$ vs. $18.3 \%)$ or median survival ( 25 vs. 24.7 weeks), but topotecan therapy led to better palliation of symptoms and less interference with daily activities. ${ }^{82}$ The added value of topotecan in symptom palliation has been confirmed by 2 other randomized studies. ${ }^{83,84}$ Eckardt et al. ${ }^{83}$ evaluated oral and intravenous topotecan as a second-line agent in 304 patients ranging in age from 35 to 82 years and reported objective symptom palliation with both formulations. Similarly, O'Brien et al. ${ }^{84}$ compared oral topotecan with best supportive care in a randomized study of 141 patients with poor performance status who were deemed unsuitable for combination chemotherapy. Topotecan administration was fairly well tolerated, with $99 \%$ of the patients taking more than $90 \%$ of their prescribed doses. Active therapy was associated with improved survival (13.9 vs. 25.9 weeks; $P<.01)$ and better quality of life, especially in patients whose disease relapsed shortly (within 60 days) after completion of frontline chemotherapy. 
Small Cell Lung Cancer in the Elderly

In summary, no elderly-specific studies have been conducted in the salvage therapy setting for SCLC, and therefore definitive recommendations for elderly patients are difficult to make. Importantly, salvage therapy has limited impact on survival and is offered to patients mainly for qualitative benefits. Therefore, it should only be offered to fit elderly patients. The favorable tolerability profile of oral topotecan suggests that it would be a reasonable option for elderly patients when it becomes available for routine use. Elderly patients should be encouraged to participate in clinical trials that use novel agents as monotherapy or in combination with currently available regimens.

\section{Novel Agents on the Horizon}

SCLC outcomes are likely to be further improved by the incorporation of novel targeted agents into existing treatment paradigms. Biologic agents can provide additional advantages for the elderly, based on their potential for a favorable tolerability profile. Various classes of compounds, including antiangiogenic agents, antisense Bcl-2 inhibitors, histone deacetylase inhibitors, and sonic hedgehog signaling pathway inhibitors, are in preclinical and clinical development.

The addition of bevacizumab, a monoclonal antibody against vascular endothelial growth factor (VEGF), to standard chemotherapy (paclitaxel/carboplatin) in patients with recurrent or advanced nonsmall cell lung cancer (NSCLC) led to a 21\% and 34\% reduction in the risk for death and disease progression, respectively. ${ }^{85}$ The enthusiasm generated by this result fueled the ongoing effort to incorporate anti-VEGF therapy into the frontline treatment of SCLC. ${ }^{86}$

ECOG conducted a phase II trial of bevacizumab in combination with frontline chemotherapy (cisplatin and etoposide) in 69 patients (median age, 65.5 years) with extensive-stage SCLC. The response rate was $69 \%$ and median progression-free survival was 4.7 months, whereas the median survival was 11.1 months. ${ }^{87}$

A similarly designed study by the CALGB added bevacizumab to combination cisplatin/irinotecan for frontline therapy of extensive-stage SCLC. In a preliminary analysis of the 70 enrolled patients, median progression-free survival was measured at 7.1 months, with median overall survival of 11.7 months. Although the study failed in its primary end point of exceeding the median survival of 12.8 months reported with cisplatin/irinotecan combination in Japanese patients, ${ }^{54}$ it modestly surpassed the median overall survival reported from most of the recent trials of extensive-stage SCLC in patients in the United States. ${ }^{88}$ Although these results are promising, none were derived from an elderly-specific or elderly-enriched patient population.

In the ECOG 4599 trial studying bevacizumab in advanced or relapsed NSCLC, more than $40 \%$ of enrolled patients were older than 65 years, ${ }^{85}$ indicating a fair representation and suggesting that this would be generalizable to the entire population of elderly patients with NSCLC. However, an unplanned secondary analysis of the data compared outcome according to the type of treatment received within the elderly ( $>70$ years) and younger ( $<70$ years) patient groups. The addition of bevacizumab to standard chemotherapy led to an increased response rate in both the elderly ( $29 \%$ vs. $17 \%$ ) and younger patients (36\% vs. $14 \%){ }^{89}$ However, although this translated into an improved median survival time within the younger group (12.8 vs. 9.6 months; $P=.0027$ ), no improvement occurred in the elderly group (12.1 vs. 11.3 months; $P=.4$ ).

Although secondary analysis to answer questions not raised a priori is unreliable and may be misleading, the increased toxicity and consequent increase in treatment-related deaths ( $1.8 \%$ vs. $6.3 \%)$ observed in elderly patients treated with bevacizumab compared with those treated with chemotherapy alone calls for caution in integrating targeted agents in elderly patients. Nevertheless, the increasing number of novel targeted agents entering the clinical arena is promising for transforming the treatment of SCLC, especially in the elderly. It will be important to study these agents and combinations in elderly-specific or -enriched trials to obtain relevant safety and efficacy data that can be applied to treatment.

\section{Conclusions}

The burden of SCLC in the elderly population remains large despite a decline in incidence in recent decades. Limited progress has been achieved in the past decade to improve the outcome for patients with SCLC. Platinum-based combination therapy should be used in the frontline setting for fit elderly patients, with addition of thoracic radiotherapy, preferably as a single daily dose. PCI benefits elderly patients with limitedstage SCLC and should be judiciously used. Although 
Owonikoko and Ramalingam

the potential risk for neurotoxicity is a concern, this beneficial intervention should not be withheld without conclusive negative evidence. However, in extensivestage SCLC, the therapeutic index of PCI in elderly patients is yet to be evaluated. The ideal salvage therapy for relapsed disease in the elderly has not been well studied and requires the decision regarding therapy and the choice of agents to be individualized, with particular attention to quality of life. In this regard, topotecan in parenteral and oral formulations is tolerable and has reproducible activity in refractory disease. It has promise for treating the elderly because it improves symptom palliation. Although the era of biologic agents is in full bloom in oncology care, SCLC therapy has yet to benefit from the promise held by these agents.

\section{References}

1. Govindan R, Page N, Morgensztern D, et al. Changing epidemiology of small-cell lung cancer in the United States over the last 30 years: analysis of the surveillance, epidemiologic, and end results database. J Clin Oncol 2006;24:4539-4544.

2. Owonikoko TK, Ragin CC, Belani CP, et al. Lung cancer in elderly patients: an analysis of the SEER database. J Clin Oncol 2007;25: 5570-5577.

3. Hutchins LF, Unger JM, Crowley JJ, et al. Underrepresentation of patients 65 years of age or older in cancer-treatment trials. N Engl J Med 1999;341:2061-2067.

4. Jatoi A, Hillman S, Stella P, et al. Should elderly non-small-cell lung cancer patients be offered elderly-specific trials? Results of a pooled analysis from the North Central Cancer Treatment Group. J Clin Oncol 2005;23:9113-9119.

5. Jennens RR, Giles GG, Fox RM. Increasing underrepresentation of elderly patients with advanced colorectal or non-small-cell lung cancer in chemotherapy trials. Intern Med J 2006;36:216-220.

6. Murthy VH, Krumholz HM, Gross CP. Participation in cancer clinical trials: race-, sex-, and age-based disparities. JAMA 2004;291: 2720-2726.

7. McLean AJ, Le Couteur DG. Aging biology and geriatric clinical pharmacology. Pharmacol Rev 2004;56:163-184.

8. Khuder SA. Effect of cigarette smoking on major histological types of lung cancer: a meta-analysis. Lung Cancer 2001;31:139-148.

9. Barbone F, Bovenzi M, Cavallieri F, Stanta G. Cigarette smoking and histologic type of lung cancer in men. Chest 1997;112: 1474-1479.

10. Hoffmann D, Hoffmann I, El-Bayoumy K. The less harmful cigarette: a controversial issue. A tribute to Ernst L. Wynder. Chem Res Toxicol 2001;14:767-790.

11. Gaspar LE, Gay EG, Crawford J, et al. Limited-stage small-cell lung cancer (stages I-III): observations from the National Cancer Data Base. Clin Lung Cancer 2005;6:355-360.

12. Ettinger DS, Aisner J. Changing face of small-cell lung cancer: real and artifact. J Clin Oncol 2006;24:4526-4527.

13. Evans WK, Shepherd FA, Feld R, et al. VP-16 and cisplatin as firstline therapy for small-cell lung cancer. J Clin Oncol 1985;3:1471-1477.
14. Sundstrom S, Bremnes RM, Kaasa S, et al. Cisplatin and etoposide regimen is superior to cyclophosphamide, epirubicin, and vincristine regimen in small-cell lung cancer: results from a randomized phase III trial with 5 years' follow-up. J Clin Oncol 2002;20:4665-4672.

15. Johnson BE, Bridges JD, Sobczeck M, et al. Patients with limited-stage small-cell lung cancer treated with concurrent twice-daily chest radiotherapy and etoposide/cisplatin followed by cyclophosphamide, doxorubicin, and vincristine. J Clin Oncol 1996;14:806-813.

16. Gatzemeier U, Hossfeld DK, Neuhauss R, et al. Phase II and III studies with carboplatin in small cell lung cancer. Semin Oncol 1992; 19(1 Suppl 2):28-36.

17. Boulikas T, Vougiouka M. Cisplatin and platinum drugs at the molecular level [review]. Oncol Rep 2003;10:1663-1682.

18. Skarlos DV, Samantas E, Kosmidis P, et al. Randomized comparison of etoposide-cisplatin vs. etoposide-carboplatin and irradiation in small-cell lung cancer. A Hellenic Co-operative Oncology Group study. Ann Oncol 1994;5:601-607.

19. Okamoto $H$, Watanabe $K$, Nishiwaki $Y$, et al. Phase II study of area under the plasma-concentration-versus-time curve-based carboplatin plus standard-dose intravenous etoposide in elderly patients with small-cell lung cancer. J Clin Oncol 1999;17:3540-3545.

20. Matsui K, Masuda N, Yana T, et al. Carboplatin calculated with Chatelut's formula plus etoposide for elderly patients with small-cell lung cancer. Intern Med 2001;40:603-606.

21. Murray N, Grafton C, Shah A, et al. Abbreviated treatment for elderly, infirm, or noncompliant patients with limited-stage small-cell lung cancer. J Clin Oncol 1998;16:3323-3328.

22. Shibata K, Kasahara K, Nakatsumi Y, et al. Carboplatin and etoposide in the treatment of elderly small cell lung cancer (SCLC). Lung Cancer 1997;18:54a.

23. Fukuda M, Soda $\mathrm{H}$, Soejima $\mathrm{Y}$, et al. A phase I trial of carboplatin and etoposide for elderly (>or=75 year-old) patients with small-cell lung cancer. Cancer Chemother Pharmacol 2006;58:601-606.

24. Goss GD, Vincent M, Germond C, et al. Combination chemotherapy with teniposide (VM26) and carboplatin in small cell lung cancer. Am J Clin Oncol 1993;16:295-300.

25. Michel G, Leyvraz S, Bauer J, et al. Weekly carboplatin and VM-26 for elderly patients with small-cell lung cancer. Ann Oncol 1994;5:369-370.

26. Evans WK, Radwi A, Tomiak E, et al. Oral etoposide and carboplatin. Effective therapy for elderly patients with small cell lung cancer. Am J Clin Oncol 1995;18:149-155.

27. Matsui K, Masuda N, Fukuoka M, et al. Phase II trial of carboplatin plus oral etoposide for elderly patients with small-cell lung cancer. Br J Cancer 1998;77:1961-1965.

28. Quoix E, Breton JL, Daniel C, et al. Etoposide phosphate with carboplatin in the treatment of elderly patients with small-cell lung cancer: a phase II study. Ann Oncol 2001;12:957-962.

29. Larive $S$, Bombaron P, Riou R, et al. Carboplatin-etoposide combination in small cell lung cancer patients older than 70 years: a phase II trial. Lung Cancer 2002;35:1-7.

30. Okamoto H, Naoki K, Narita Y, et al. A combination chemotherapy of carboplatin and irinotecan with granulocyte colony-stimulating factor (G-CSF) support in elderly patients with small cell lung cancer. Lung Cancer 2006;53:197-203.

31. Jeremic B, Shibamoto Y, Acimovic L, Milisavljevic S. Carboplatin, etoposide, and accelerated hyperfractionated radiotherapy for elderly patients with limited small cell lung carcinoma: a phase II study. Cancer 1998;82:836-841.

32. Girling DJ. Comparison of oral etoposide and standard intravenous multidrug chemotherapy for small-cell lung cancer: a stopped 
Small Cell Lung Cancer in the Elderly

multicentre randomised trial. Medical Research Council Lung Cancer Working Party. Lancet 1996;348:563-566.

33. Souhami RL, Spiro SG, Rudd RM, et al. Five-day oral etoposide treatment for advanced small-cell lung cancer: randomized comparison with intravenous chemotherapy. J Natl Cancer Inst 1997;89:577-580.

34. Ardizzoni A, Favaretto A, Boni L, et al. Platinum-etoposide chemotherapy in elderly patients with small-cell lung cancer: results of a randomized multicenter phase II study assessing attenuateddose or full-dose with lenograstim prophylaxis—a Forza Operativa Nazionale Italiana Carcinoma Polmonare and Gruppo Studio Tumori Polmonari Veneto (FONICAP-GSTPV) study. J Clin Oncol 2005;23:569-575.

35. Findlay MP, Griffin AM, Raghavan D, et al. Retrospective review of chemotherapy for small cell lung cancer in the elderly: does the end justify the means? Eur J Cancer 1991;27:1597-1601.

36. Shepherd FA, Amdemichael E, Evans WK, et al. Treatment of small cell lung cancer in the elderly. J Am Geriatr Soc 1994;42:64-70.

37. Pignon JP, Arriagada R, Ihde DC, et al. A meta-analysis of thoracic radiotherapy for small-cell lung cancer. N Engl J Med 1992;327: 1618-1624.

38. Arriagada R, Pignon JP, Ihde DC, et al. Effect of thoracic radiotherapy on mortality in limited small cell lung cancer. A meta-analysis of 13 randomized trials among 2,140 patients. Anticancer Res 1994;14(1B):333-335.

39. Warde P, Payne D. Does thoracic irradiation improve survival and local control in limited-stage small-cell carcinoma of the lung? A meta-analysis. J Clin Oncol 1992;10:890-895.

40. Faivre-Finn $\mathrm{C}$, Lee LW, Lorigan $\mathrm{P}$, et al. Thoracic radiotherapy for limited-stage small-cell lung cancer: controversies and future developments. Clin Oncol (R Coll Radiol) 2005;17:591-598.

41. Socinski MA, Bogart JA. Limited-stage small-cell lung cancer: the current status of combined-modality therapy. J Clin Oncol 2007; 25:4137-4145.

42. Turrisi AT III, Kim K, Blum R, et al. Twice-daily compared with once-daily thoracic radiotherapy in limited small-cell lung cancer treated concurrently with cisplatin and etoposide. N Engl J Med 1999;340:265-271.

43. Movsas B, Moughan J, Komaki R, et al. Radiotherapy patterns of care study in lung carcinoma. J Clin Oncol 2003;21:4553-4559.

44. Pijls-Johannesma M, De Ruysscher D, Vansteenkiste J, et al. Timing of chest radiotherapy in patients with limited stage small cell lung cancer: a systematic review and meta-analysis of randomised controlled trials. Cancer Treat Rev 2007;33:461-473.

45. Yuen AR, Zou G, Turrisi AT, et al. Similar outcome of elderly patients in intergroup trial 0096: cisplatin, etoposide, and thoracic radiotherapy administered once or twice daily in limited stage small cell lung carcinoma. Cancer 2000;89:1953-1960.

46. Schild SE, Stella PJ, Brooks BJ, et al. Results of combined-modality therapy for limited-stage small cell lung carcinoma in the elderly. Cancer 2005;103:2349-2354.

47. Schild SE, Bonner JA, Hillman S, et al. Results of a phase II study of high-dose thoracic radiation therapy with concurrent cisplatin and etoposide in limited-stage small-cell lung cancer (NCCTG 9520-53). J Clin Oncol 2007;25:3124-3129.

48. Bogart JA, Herndon JE II, Lyss AP, et al. 70 Gy thoracic radiotherapy is feasible concurrent with chemotherapy for limited-stage smallcell lung cancer: analysis of Cancer and Leukemia Group B study 39808. Int J Radiat Oncol Biol Phys 2004;59:460-468.
49. Johnson BE, Crawford J, Downey RJ, et al. Small cell lung cancer clinical practice guidelines in oncology. J Natl Compr Canc Netw 2006;4:602-622.

50. Mascaux C, Paesmans M, Berghmans T, et al. A systematic review of the role of etoposide and cisplatin in the chemotherapy of small cell lung cancer with methodology assessment and meta-analysis. Lung Cancer 2000;30:23-36.

51. Pujol JL, Carestia L, Daures JP. Is there a case for cisplatin in the treatment of small-cell lung cancer? A meta-analysis of randomized trials of a cisplatin-containing regimen versus a regimen without this alkylating agent. Br J Cancer 2000;83:8-15.

52. Bishop JF, Raghavan D, Stuart-Harris R, et al. Carboplatin (CBDCA, JM-8) and VP-16-213 in previously untreated patients with small-cell lung cancer. J Clin Oncol 1987;5:1574-1578.

53. Okamoto H, Watanabe K, Kunikane H, et al. Randomised phase III trial of carboplatin plus etoposide vs split doses of cisplatin plus etoposide in elderly or poor-risk patients with extensive disease small-cell lung cancer: JCOG 9702. Br J Cancer 2007;97:162-169.

54. Noda K, Nishiwaki Y, Kawahara M, et al. Irinotecan plus cisplatin compared with etoposide plus cisplatin for extensive small-cell lung cancer. N Engl J Med 2002;346:85-91.

55. Hanna N, Bunn PA Jr, Langer C, et al. Randomized phase III trial comparing irinotecan/cisplatin with etoposide/cisplatin in patients with previously untreated extensive-stage disease small-cell lung cancer. J Clin Oncol 2006;24:2038-2043.

56. Lara P, Redman M, Lenz H, et al. Cisplatin (Cis)/etoposide (VP16) compared to cis/irinotecan (CPT11) in extensive-stage small cell lung cancer (E-SCLC): pharamacogenomic (PG) and comaparative toxicity analysis of JCOG 9511 and SWOG 0124 [abstract]. J Clin Oncol 2007;25(Suppl 1):390s. Abstract 7524.

57. Hermes A, Bergman B, Bremnes R, et al. A randomized phase III trial of rintecan plus carboplatin versus etoposide plus carboplatin in patients with small cell lung cancer, extensive disease (SCLC-ED): IRIS-Study [abstract]. J Clin Oncol 2007;25(Suppl 1):390s. Abstract 7523.

58. Arriagada R, Pignon JP, Laplanche A, Le Chevalier T. Prophylactic cranial irradiation for small-cell lung cancer. Lancet 1997;349:138.

59. Arriagada R, Le Chevalier T, Borie F, et al. Prophylactic cranial irradiation for patients with small-cell lung cancer in complete remission. J Natl Cancer Inst 1995;87:183-190.

60. Gregor A, Cull A, Stephens RJ, et al. Prophylactic cranial irradiation is indicated following complete response to induction therapy in small cell lung cancer: results of a multicentre randomised trial. United Kingdom Coordinating Committee for Cancer Research (UKCCCR) and the European Organization for Research and Treatment of Cancer (EORTC). Eur J Cancer 1997;33:1752-1758.

61. Meert AP, Paesmans M, Berghmans T, et al. Prophylactic cranial irradiation in small cell lung cancer: a systematic review of the literature with meta-analysis. BMC Cancer 2001;1:5.

62. Auperin A, Arriagada R, Pignon JP, et al. Prophylactic cranial irradiation for patients with small-cell lung cancer in complete remission. Prophylactic Cranial Irradiation Overview Collaborative Group. N Engl J Med 1999;341:476-484.

63. Cranial irradiation for preventing brain metastases of small cell lung cancer in patients in complete remission. Cochrane Database Syst Rev 2000:CD002805.

64. Arriagada R, Le Chevalier T, Riviere A, et al. Patterns of failure after prophylactic cranial irradiation in small-cell lung cancer: analysis of 505 randomized patients. Ann Oncol 2002;13:748-754. 
Owonikoko and Ramalingam

65. Ludbrook JJ, Truong PT, MacNeil MV, et al. Do age and comorbidity impact treatment allocation and outcomes in limited stage smallcell lung cancer? a community-based population analysis. Int J Radiat Oncol Biol Phys 2003;55:1321-1330.

66. Kotalik J, Yu E, Markman BR, Evans WK. Practice guideline on prophylactic cranial irradiation in small-cell lung cancer. Int J Radiat Oncol Biol Phys 2001;50:309-316.

67. Meyers CA, Byrne KS, Komaki R. Cognitive deficits in patients with small cell lung cancer before and after chemotherapy. Lung Cancer 1995;12:231-235.

68. Johnson BE, Becker B, Goff WB II, et al. Neurologic, neuropsychologic, and computed cranial tomography scan abnormalities in 2- to 10-year survivors of small-cell lung cancer. J Clin Oncol 1985;3: 1659-1667.

69. Lee JS, Umsawasdi T, Lee YY, et al. Neurotoxicity in long-term survivors of small cell lung cancer. Int J Radiat Oncol Biol Phys 1986;12:313-321.

70. Johnson BE, Patronas N, Hayes W, et al. Neurologic, computed cranial tomographic, and magnetic resonance imaging abnormalities in patients with small-cell lung cancer: further follow-up of 6- to 13year survivors. J Clin Oncol 1990;8:48-56.

71. Ohonoshi $\mathrm{T}$, Ueoka H, Kawahara S, et al. Comparative study of prophylactic cranial irradiation in patients with small cell lung cancer achieving a complete response: a long-term follow-up result. Lung Cancer 1993;10:47-54.

72. Shaw EG, Su JQ, Eagan RT, et al. Prophylactic cranial irradiation in complete responders with small-cell lung cancer: analysis of the Mayo Clinic and North Central Cancer Treatment Group data bases. J Clin Oncol 1994;12:2327-2332.

73. Cull A, Gregor A, Hopwood P, et al. Neurological and cognitive impairment in long-term survivors of small cell lung cancer. Eur J Cancer 1994:30A:1067-1074.

74. Wolfson AH, Bains Y, Lu J, et al. Twice-daily prophylactic cranial irradiation for patients with limited disease small-cell lung cancer with complete response to chemotherapy and consolidative radiotherapy: report of a single institutional phase II trial. Am J Clin Oncol 2001; 24:290-295.

75. Seute T, Leffers P, ten Velde GP, Twijnstra A. Neurologic disorders in 432 consecutive patients with small cell lung carcinoma. Cancer 2004;100:801-806.

76. Postmus PE, Haaxma-Reiche H, Gregor A, et al. Brain-only metastases of small cell lung cancer; efficacy of whole brain radiotherapy. An EORTC phase II study. Radiother Oncol 1998;46:29-32.

77. Postmus PE, Haaxma-Reiche H, Smit EF, et al. Treatment of brain metastases of small-cell lung cancer: comparing teniposide and teniposide with whole-brain radiotherapy - a phase III study of the European Organization for the Research and Treatment of Cancer Lung Cancer Cooperative Group. J Clin Oncol 2000;18:3400-3408.
78. Seute T, Leffers P, Wilmink JT, et al. Response of asymptomatic brain metastases from small-cell lung cancer to systemic first-line chemotherapy. J Clin Oncol 2006;24:2079-2083.

79. van Oosterhout AG, van de Pol M, ten Velde GP, Twijnstra A. Neurologic disorders in 203 consecutive patients with small cell lung cancer. Results of a longitudinal study. Cancer 1996;77: 1434-1441.

80. Souhami RL, Law K. Longevity in small cell lung cancer. A report to the Lung Cancer Subcommittee of the United Kingdom Coordinating Committee for Cancer Research. Br J Cancer 1990;61: 584-589.

81. Slotman B, Faivre-Finn C, Kramer G, et al. Prophylactic cranial irradiation in extensive small-cell lung cancer. N Engl J Med 2007; 357:664-672.

82. von Pawel J, Schiller JH, Shepherd FA, et al. Topotecan versus cyclophosphamide, doxorubicin, and vincristine for the treatment of recurrent small-cell lung cancer. J Clin Oncol 1999;17: 658-667.

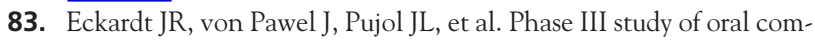
pared with intravenous topotecan as second-line therapy in smallcell lung cancer. J Clin Oncol 2007;25:2086-2092.

84. O'Brien ME, Ciuleanu TE, Tsekov H, et al. Phase III trial comparing supportive care alone with supportive care with oral topotecan in patients with relapsed small-cell lung cancer. J Clin Oncol 2006;24: 5441-5447.

85. Sandler A, Gray R, Perry MC, et al. Paclitaxel-carboplatin alone or with bevacizumab for non-small-cell lung cancer. N Engl J Med 2006;355:2542-2550.

86. Arnold AM, Seymour L, Smylie M, et al. Phase II study of vandetanib or placebo in small-cell lung cancer patients after complete or partial response to induction chemotherapy with or without radiation therapy: National Cancer Institute of Canada Clinical Trials Group Study BR.20. J Clin Oncol 2007;25:4278-4284.

87. Sandler A, Szwaric S, Dowlati A, et al. A phase II study of cisplatin (P) plus etoposide (E) plus bevacizumab (B) for previously untreated extensive stage small cell lung cancer (SCLC) (E3501): a trial of the Eastern Cooperative Oncology Group [abstract]. J Clin Oncol 2007;25(Suppl 1):400s. Abstract 7564.

88. Ready N, Dudek AZ, Wang XF, et al. CALGB 30306: A phase II study of cisplatin (C), irinotecan (I) and bevacizumab (B) for untreated extensive stage small cell lung cancer (ES-SCLC) [abstract]. J Clin Oncol 2007;25(Suppl 1):400s. Abstract 7563.

89. Ramalingam SS, Dahlberg SE, Langer CJ, et al. Outcomes for elderly advanced stage non-small cell lung cancer (NSCLC) patients (pts) treated with bevacizumab (B) in combination with carboplatin (C) and paclitaxel (P): analysis of Eastern Cooperative Oncology Group (ECOG) 4599 study [abstract]. J Clin Oncol 2007;25 (Suppl 1):393s. Abstract 7535. 